\title{
Gulf Fritillary Butterfly, Agraulis vanillae (Linnaeus) (Insecta: Lepidoptera: Nymphalidae) ${ }^{1}$
}

Jaret C. Daniels ${ }^{2}$

\section{Introduction}

The Gulf fritillary, Agraulis vanillae (Linnaeus), is a brightly colored butterfly common across extreme southern portions of the United States. At home in most open, sunny habitats, it frequents roadsides, disturbed sites, fields, open woodlands, pastures, yards, and parks. It is a regular in most butterfly gardens, including those in more urban settings.

\section{Distribution}

The Gulf fritillary occurs throughout the southern United States southward through Mexico, Central America and the West Indies to South America. In Florida, it can be found in all 67 counties. The butterfly undergoes distinct seasonal movements each year. Adults move northward in spring and form temporarily breeding colonies throughout the southeast. Individual vagrants may occasionally reach into the central U.S., but rarely into the Midwest. Starting in late summer and continuing through fall, huge numbers of adults migrate southward into peninsular Florida. Adults overwinter in frost-free portions of their range.

\section{Description}

Adult: The Gulf fritillary is a medium-sized butterfly with elongated forewings. Adults have a wingspan range of 65 to $95 \mathrm{~mm}$. Females are generally larger than males. The sexes are dimorphic. The upper surface of the wings is bright orange with black markings. Females are somewhat darker and more extensively marked. The forewing cell contains three black-rimmed white spots. The undersides of the wings are brown with elongated silvery-white spots.

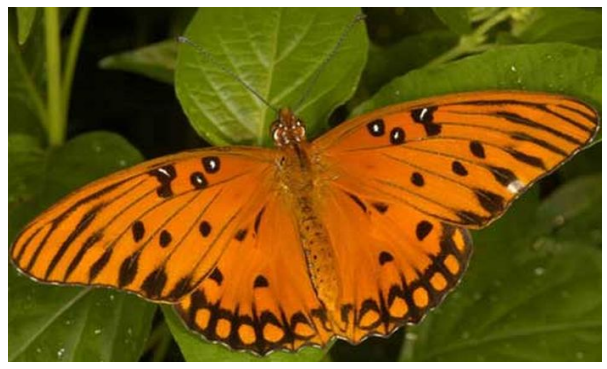

Figure 1. Adult Gulf fritillary butterfly, Agraulis vanillae Linnaeus.

1. This document is EENY-423, one of a series of Featured Creatures from the Entomology and Nematology Department, Florida Cooperative Extension Service, Institute of Food and Agricultural Sciences, University of Florida. Published: February 2009. This document is also available on Featured Creatures Website at http://creatures.ifas.ufl.edu. Please visit the EDIS Website at http://edis.ifas.ufl.edu. Additional information on these organisms, including many color photographs, is available at the Entomology and Nematology Department website at http://entnemdept.ifas.ufl.edu/.

2. Jaret C. Daniels, assistant professor, Entomology and Nematology Department, Institute of Food and Agricultural Sciences, University of Florida, Gainesville, FL 32611.

The Institute of Food and Agricultural Sciences (IFAS) is an Equal Opportunity Institution authorized to provide research, educational information and other services only to individuals and institutions that function with non-discrimination with respect to race, creed, color, religion, age, disability, sex, sexual orientation, marital status, national origin, political opinions or affiliations. U.S. Department of Agriculture, Cooperative Extension Service, University of Florida, IFAS, Florida A. \& M. University Cooperative Extension Program, and Boards of County Commissioners Cooperating. Millie Ferrer, Interim Dean 
Eggs: The yellow eggs are laid singly on or near the hostplant.

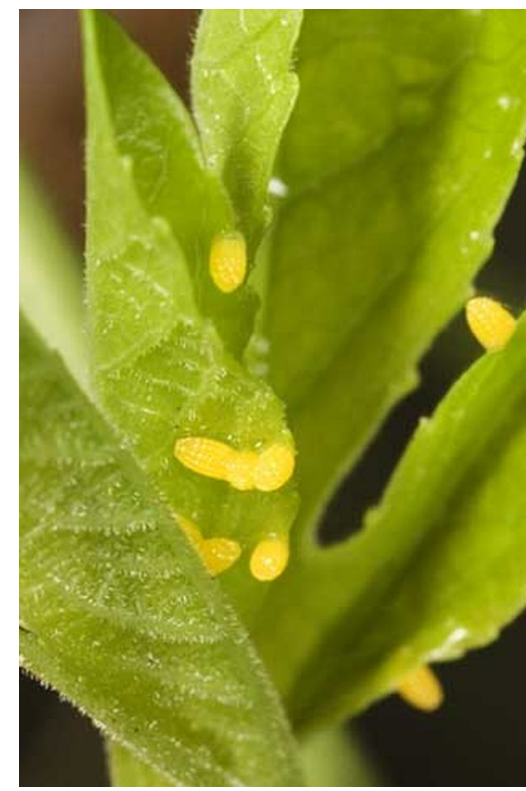

Figure 2. Eggs of the Gulf fritillary butterfly, Agraulis vanillae Linnaeus, on Maypop (purple passionflower), Passiflora incarnata L. (Passifloraceae). Credits: Jaret C. Daniels, University of Florida

Larva: The mature larva is bright orange with numerous black branched spines.

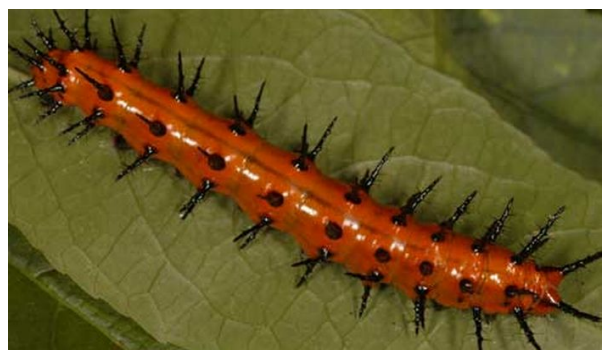

Figure 3. Mature larvae of the Gulf fritillary butterfly, Agaulis vanillae Linnaeus, on corkystem passionflower, Passiflora suberosa L. (Passifloraceae). Credits: Jaret C. Daniels, University of Florida

Pupa: The pupa is mottled brown.

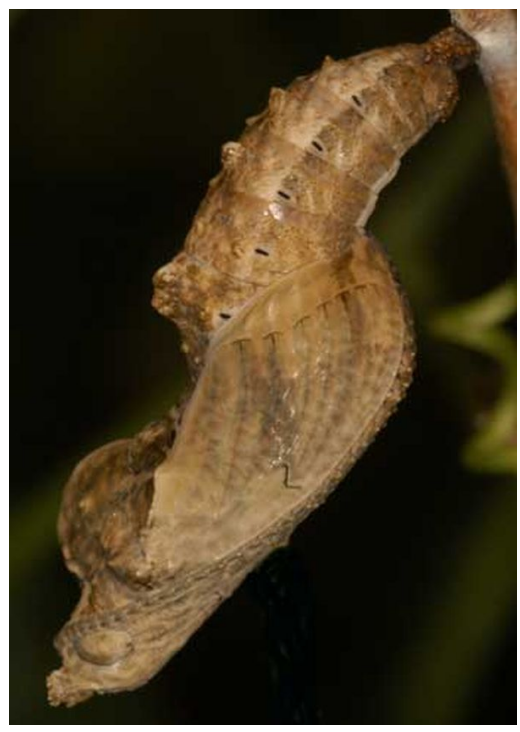

Figure 4. Pupa of the Gulf fritillary butterfly, Agaulis vanillae Linnaeus, on twig. Credits: Jaret C. Daniels, University of Florida

\section{Life Cycle and Hosts}

The Gulf fritillary produces multiple generations each year. Adults may be found in all months of the year throughout much of Florida. Adults have a quick, erratic flight but are easily drawn to nearby flowers. Females lay the small yellow eggs singly on or near leaves, stems or tendrils of purple passionflower (Passiflora incarnata L.), corkystem passionflower (Passiflora suberosa L.), yellow passionflower (Passiflora lutea L.) and several other passionflower vines. The larvae are bright orange with numerous black, branched spines. Larvae may feed on all parts of the plant and can rapidly defoliate host vines. The pupa is mottled brown and resembles a dead leaf. Adults overwinter.

\section{Selected References}

- Cech R, Tudor G. Butterflies of the East Coast: An Observer's Guide. 2005. Princeton University Press, Princeton, NJ. 345 pp.

- Daniels JC. Butterflies of Florida Field Guide. 2003. Adventure Publications, Cambridge, MN. $250 \mathrm{pp}$. 


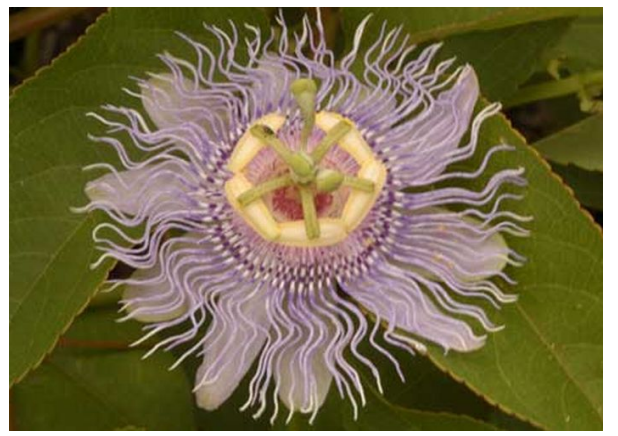

Figure 5. Purple passionflower, Passiflora incarnata L. (Passifloracaea), a host of the Gulf fritillary butterfly, Agraulis vanillae (Linneaus). Credits: Jaret C. Daniels, University of Florida

- Daniels JC. 2000. Butterflies 1: Butterflies of the Southeast. UF/IFAS. Card Set. SP 273.

- Kimball CP. 1965. The Lepidoptera of Florida; an annotated checklist. Arthropods of Florida and Neighboring Land Areas Vol. 1. Florida Department of Agriculture and Consumer Services, Division of Plant Industry. 363 pp.

- Medley JC, Fasulo TR. (1998). Florida Butterfly Tutorials. University of Florida/IFAS CD-ROM. SW 155.

- Minno MC, Butler JF, Hall DW. 2005. Florida Butterfly Caterpillars and Their Host Plants. University Press of Florida, Gainesville. 341 pp. 